Urszula Somorowska

\title{
INFERRING CHANGES \\ IN DYNAMIC GROUNDWATER STORAGE FROM RECESSION CURVE ANALYSIS OF DISCHARGE DATA
}

\begin{abstract}
Groundwater storage is an important element of terrestrial water storage. It influences the baseflow component of the river discharge which constitutes the majority of the outflow of Polish rivers. An evaluation of changes in the dynamic groundwater storage from point measurements of groundwater levels is usually a difficult task as groundwater data are scarce in time and space. Alternative approach involves recession curve analysis of discharge data. This study describes an approach to estimate the long-term changes in dynamic groundwater storage from daily discharges on a basin scale. Recession curve analysis is applied for identification of groundwater system functioning through derivation of master recession curve. The Master Recession Curve Tool developed by Lamb is used for automate analysis. Then results are coupled with a concept of nonlinear reservoir expressing discharge-storage relationship. As a result the volume of the groundwater storage and its temporal changes are derived on a yearly base, as a difference between highest values of storage during spring season and lowest values appearing in late summer or early autumn. The results show high annual variability of dynamic groundwater storage. The approach is presented on the example of lowland basin situated in central Poland, on the Mazovian Lowland (N 52 ${ }^{\circ} 14^{\prime}-\mathrm{N} 52^{\circ} 14^{\prime}$ and $\left.\mathrm{E} 11^{\circ} 10^{\prime}-\mathrm{E} 11^{\circ} 10^{\prime}\right)$.
\end{abstract}

Key words: baseflow, master recession curve, dynamic groundwater storage.

\section{INTRODUCTION}

Groundwater storage is an essential component of terrestrial water storage which influences dynamics of groundwater discharge at a basin scale. As a result it has an impact on dynamics of surface-subsurface system interaction and functioning. In humid climates outflow from groundwater storage contributes to the baseflow which is the most important component of the river discharge. In Poland the baseflow has a seasonal structure being highly influenced by climate and intensity of snow melting (Tomaszewski, 2002). During summer season it plays a crucial role by sustaining the river discharges. In extreme dry atmospheric conditions with prolonged periods of 
absence of precipitation and no recharge of groundwater resources, the dynamic water resources of aquifer are decreasing accordingly to the local physical parameters of surface-subsurface system. Thus river hydrograph reveals discharge recession considered to be a display of the depletion of dynamic groundwater resources.

Rate of depletion of groundwater storage can be inferred from observations of groundwater levels conducted at a point scale, however if these data are scarce in time and space then a reliable estimation of dynamic groundwater resources at a basin scale becomes a difficult task. The System of Hydrological and Meteorological Network conducted in Poland by the Institute of Meteorology and Water Management includes currently only 58 stations of groundwater levels observation. Such a density has only indicative aim for the country level and not for detailed hydrological studies. With the exception of point measurements of groundwater levels conducted weekly and reported in Poland till 1983 in Annuals of Groundwater, there is little up-to-date information available at a basin scale, regional scale or large scale considering seasonal and interannual groundwater variations. Even local networks of groundwater level observations do not fulfill requirements of reliable aerial estimates due to high heterogeneity of subsurface system and its storage parameters.

Thus in many hydrological studies the recession curve analysis is applied as an inverse tool for the evaluation of the volume of dynamic groundwater storage, using easily available discharge data. Baseflow is considered to be an integrated indicator of the current volume of the groundwater storage, meaning this part of the storage which contributes to the outflow and which is named as dynamic groundwater storage. Extended review of the recession analysis can be found both in Polish and international literature e.g. Jokiel (1994) and Tallaksen (1999).

This study presents a method of estimation of the long-term changes in dynamic groundwater storage based on easily available daily river discharges. Recession curve analysis is applied for identification of groundwater system functioning through derivation of master recession curve according to theoretical framework proposed by Lamb and Beven (1997). Then results are coupled with a concept of nonlinear reservoir and analytical solutions given by Wittenberg (1999). As a result the volume of storage and its temporal changes are derived on a yearly base, as a difference between highest values of storage during spring season and lowest values appearing in late summer or early autumn.

The main goal of the undertaken study was to improve an understanding of extreme hydrological events. Extreme stages of the dynamic groundwater storage were derived from extreme values of discharge data in the long-term observation period for the years 1951-2002. The approach is presented on the example of lowland basin situated in central Poland, on the Mazovian Lowland (N 52 ${ }^{\circ} 13^{\prime}-\mathrm{N} 52^{\circ} 26^{\prime}$ and E $\left.20^{\circ} 15^{\prime}-\mathrm{E} 20^{\circ} 57^{\prime}\right)$. 


\section{RECESSION ANALYSIS OF DISCHARGE DATA}

The master recession curve method provides a model of the flow from groundwater storage (Jokiel, 1987, Jokiel, 1994). It represents characteristic baseflow response to outflow from groundwater reservoir obtained through quantification of recession curves. The procedure requires measured discharges covering different seasons of the year and the wide range of discharge values. An automated method for the analysis of large number of data was proposed by Lamb and Beven (1997) and for this purpose the Master Recession Curve (MRC) tool was developed. The MRC tool enables the selection and analysis of recession curves to form an master recession curve (Lamb \& Beven, 1997). The MRC is derived by the software package without fitting of measured recession data to a priori function. Therefore the developed method is considered to be general and it gives an arbitrary form of the MRC. In this analysis the MRC tool (version revised on January 20, 2004) in form of MATLAB m-file was applied.

Commonly used representation of the recession of baseflow is the exponential function $Q_{t}=Q_{0} \cdot \exp (-t / k)$ proposed by Maillet in 1905, where $Q_{t}$ is the discharge at time t, $Q_{0}$ is the initial discharge and $k$ is the retention constant representing response time of storage. Thus the groundwater storage is in this case represented by the function $S=k \cdot Q$, implying that storage of the system is linearly proportional to the discharge. However many empirical studies have shown that the value of $k$ coefficient is not really a constant but it is dependant on the range of discharges to which it is empirically fitted (Wittenberg, Silvapalan, 1999). For this reason some authors consider the application of the nonlinear storage-discharge relationship as more physically based and adequate to real geological conditions. Thus Wittenberg (1999) has proposed the storage-discharge relation to be described by the function $S=a Q^{b}$, where a has the dimension ${ }^{\mathrm{m} 3-3 \mathrm{~b}} \mathrm{~s}^{\mathrm{b}}$ for the value of $S$ expressed in $\mathrm{m}^{3}$ and $Q$ in $\mathrm{m}^{3} / \mathrm{s}$, and $b$ is dimensionless. In this case the recession of the baseflow can be described by the equation:

$$
\mathrm{Q}_{\mathrm{t}}=\mathrm{Q}_{0}\left[1+\frac{(1-\mathrm{b}) \mathrm{Q}_{0}}{a b} \mathrm{t}\right]^{1 /(b-1)}
$$

where $b$ is a constant and $a$ is approximated by the expression

$$
\mathrm{a}=\frac{\sum\left(\mathrm{Q}_{i-1}+\mathrm{Q}_{i}\right) \Delta \mathrm{t}}{\sum\left(\mathrm{Q}_{i-1}+\mathrm{Q}_{i}\right)}
$$

with $Q_{i}$ representing the discharge at time $i$ of the observed flow recession. For practical purposes Wittenberg and Sivapalan (1999) suggested to fix the exponent of $\mathrm{b}$ as $b=0.5$ based on empirical studies and field estimates observed in many basins. Using the proposed storage-discharge relation in 
form $S=a Q^{b}$, with $Q$ approximated by equation (1), the changes in the dynamic groundwater storage can be derived as following:

$$
\Delta S=a\left(Q_{i}-Q_{i-1}\right)
$$

Furthermore, coupling $Q_{t}$ as an independent variable with the value of $\Delta S_{i}$ as dependent variable, for each time step $i$, the relationship between the contemporary value of recessing baseflow and the value of cumulated depletion of groundwater storage can be enhanced.

\section{LONG-TERM CHANGES OF DYNAMIC GROUNDWATER STORAGE - RESULTS AND DISCUSSION}

Fig. 1 shows selected recession curves extracted from the daily discharges of the Łasica basin (gauge at Władysławów) located in the central Poland on the Mazovian Lowland. The area of the basin at this gauge is $363 \mathrm{~km}^{2}$. The drainage system of the basin is composed from natural hydrographic network

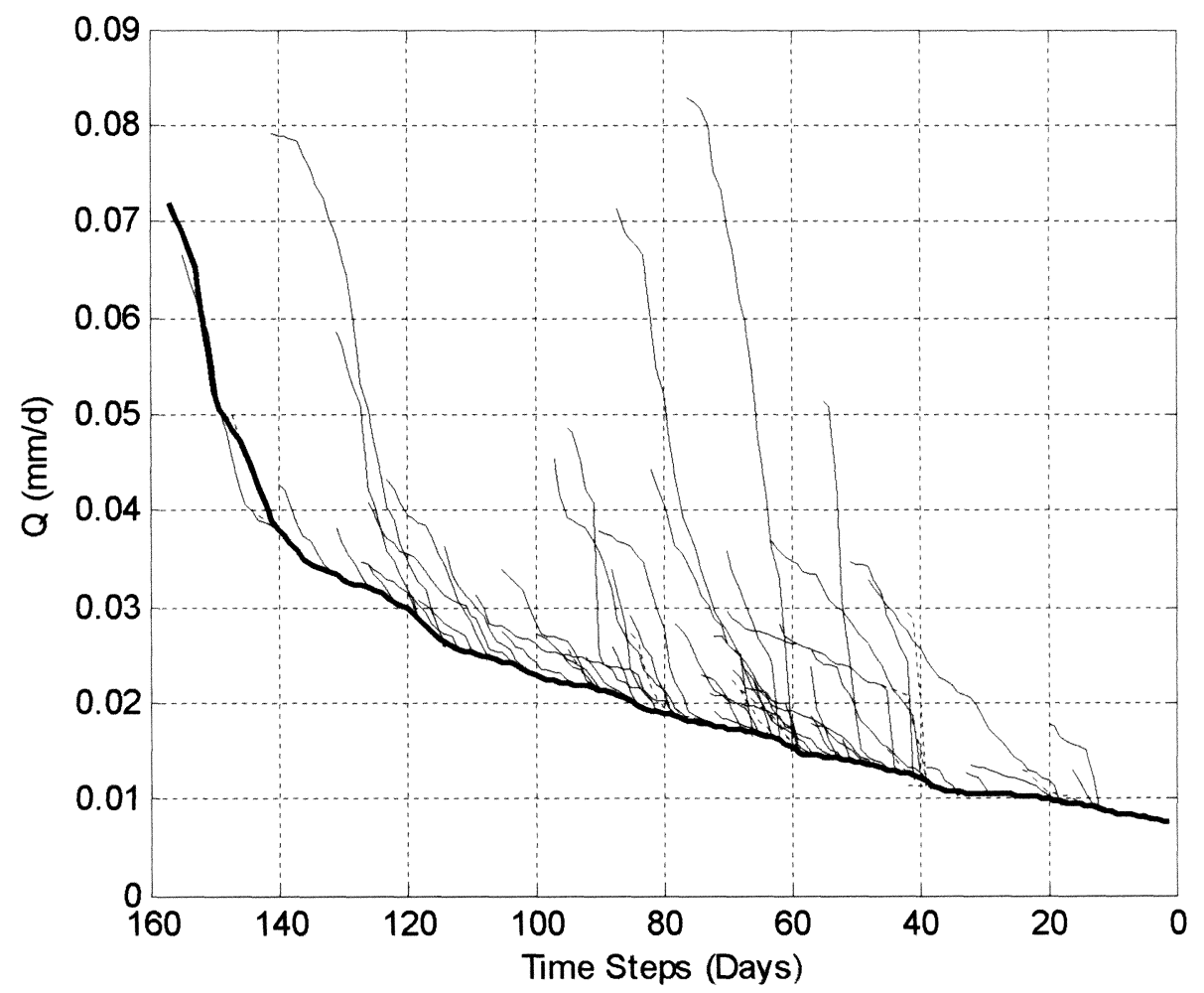

Fig. 1. Selected recession curves and the Master Recession Curve formed for months MarchApril in years 1951-2002 for the Łasica basin using MRC tool. 

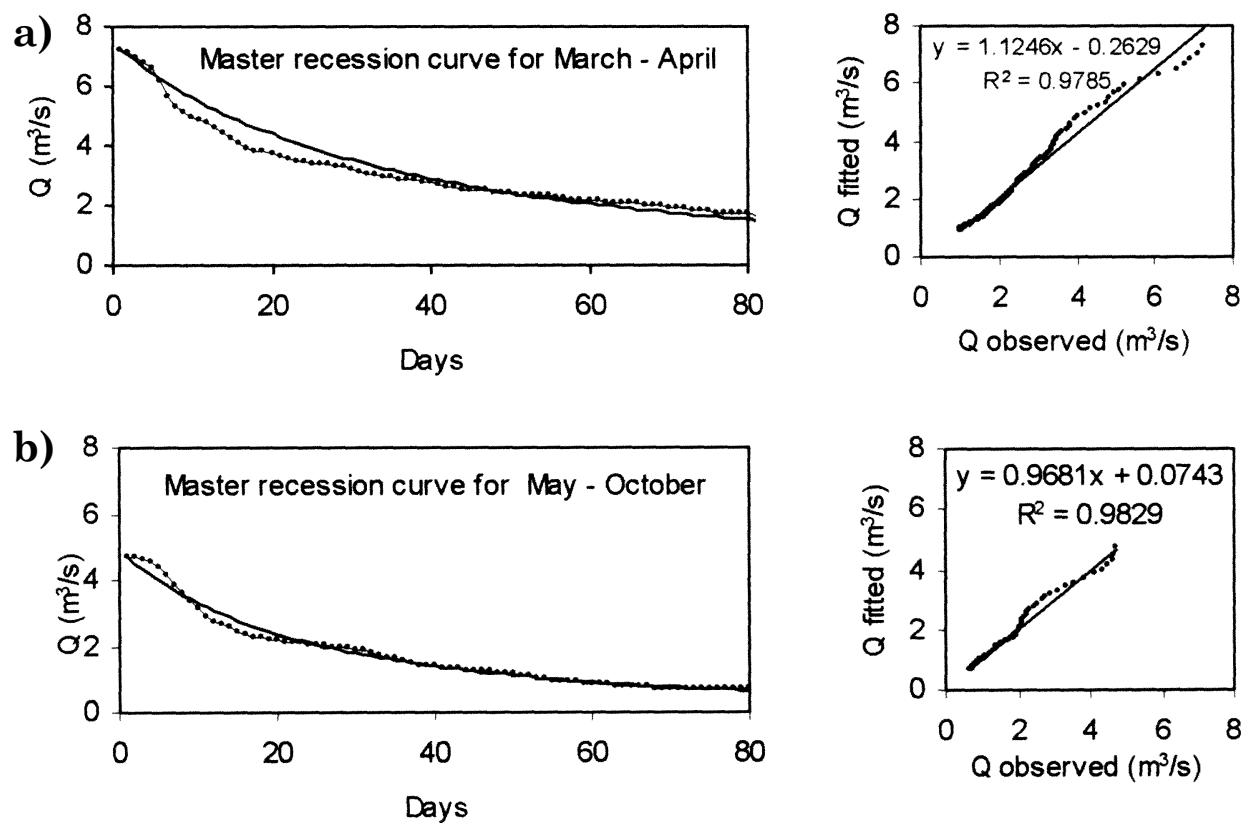

Fig. 2. Master Recession Curves formed by MRC tool and fitted by analytical equation accompanied by goodness of fit for months March-April (a) and for months May-October (b).

and artificial channels draining lowland territory in which wetlands areas constitute considerable part. Long-term data of discharges for the period 1951-2002 were used in this analysis. Extracted curves comprise 137 recession curves for spring months (March-April) and 392 recession curves for months May-October. Such a split according to time of the year is due to the seasonality of groundwater levels which represent maximum storage values in spring and then, usually when decreasing, they correspond to the depleted groundwater resources in summer or early autumn. Master recession curve was built based on the lowest "tails" of the recessions and sorting the curves in decreasing order by use of MRC tool. Fitting the Wittenberg function expressed in equation (1) to the master recession curves, the coefficient of $a$ was calculated according to equation (2). The coefficient of correlation between discharges from master recession curve and fitted curve was very high showing the good quality of fit (Fig. 2). Using the fitted parameter values of $a$, the sample recession curves were derived (Fig. 3a), separately for spring and summer conditions. For the purpose of comparison both curves are assumed to start from an arbitrary value of $Q_{0}$, chosen as the highest observed discharge. The curve derived for summer conditions is situated below the curve for spring conditions, which displays faster depletion of groundwater storage in summer then in spring. Relative storage deficits considered according to Lamb \& Beven (1997) as depletion of water storage below the storage associated with the discharge $\mathrm{Q}_{0}$, are derived and displayed in Fig. 3b. 

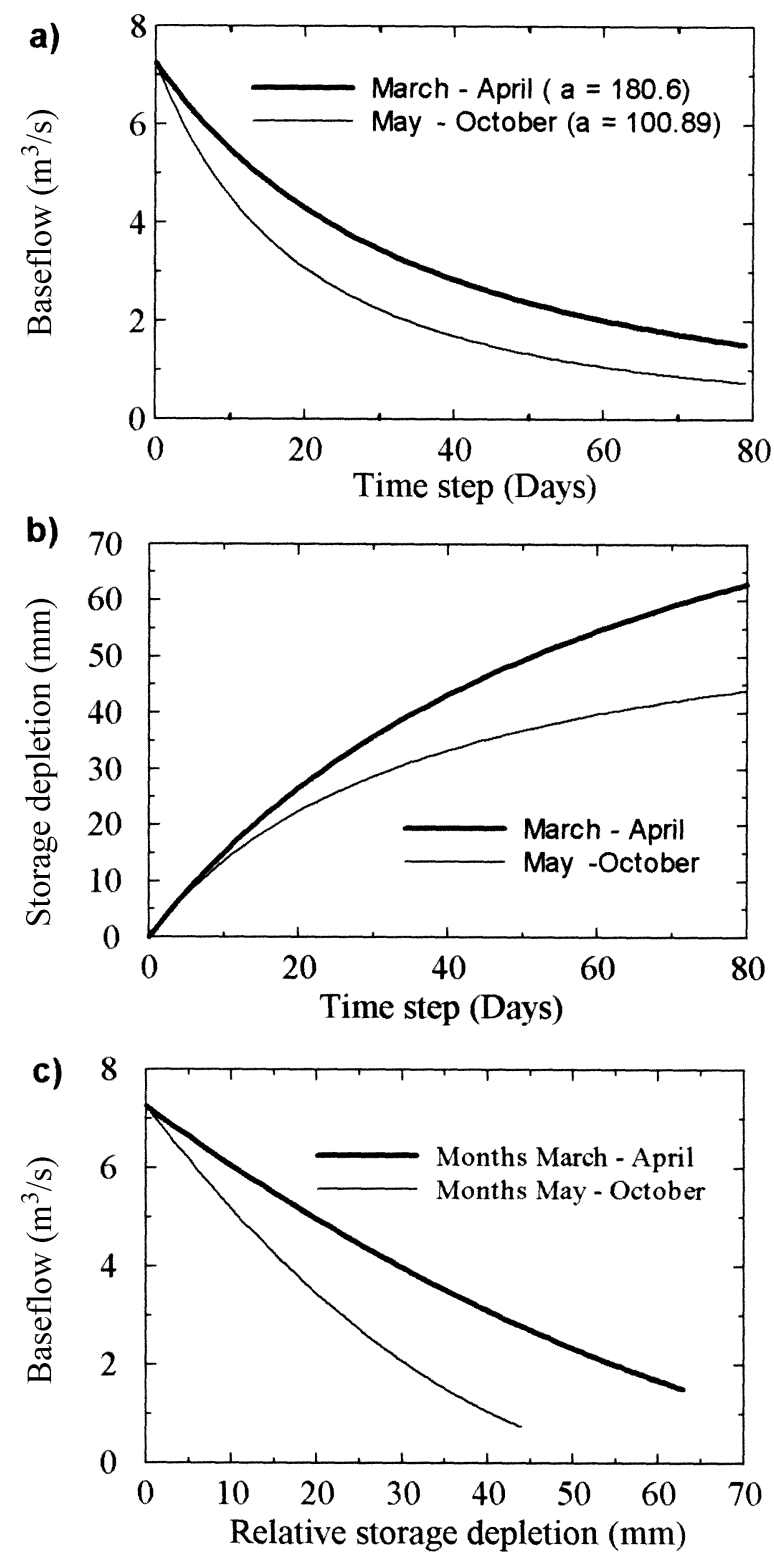

Fig. 3. Synthetic recession curves (a), relative storage deficits (b) and the discharge-storage relationships (c) for spring and summer seasons. 
Coupling values of recessing discharges with values of relative deficits of groundwater storage, the relationship $\Delta \mathrm{S}-\mathrm{Q}$ was established. The value of relative deficits developed in spring are higher than in summer due to much smaller slope of the $\mathrm{Q}-\Delta \mathrm{S}$ relationship for spring then for summer. The decrease of discharge value causes the higher decrease of groundwater storage in spring than in summer, if considered in implicit values. This is due to the higher retention in spring season then in summer. However, in summer, the faster decrease of the discharges is observed.

Based on the relationship $S=a Q^{b}$ fitted above, the extreme values of dynamic groundwater storage were derived and then associated yearly storage depletion was calculated. Fig. 4a shows differences in extreme values of discharge examined in long-term period of years 1951-2002. The range of observed amplitude of yearly discharges is $1-8 \mathrm{~m}^{3}$. The observed values of storage depletion varies in the range of $34-112 \mathrm{~mm}$, with the average value of $\Delta \mathrm{S}=68 \mathrm{~mm}$ (Fig. 4b). Relatively small storage depletion considered on a yearly basis can be associated with dry years, with low values of maximum discharges. The highest storage depletion is observed in years of considerable flood in spring and followed by appearance of low flows in summer.

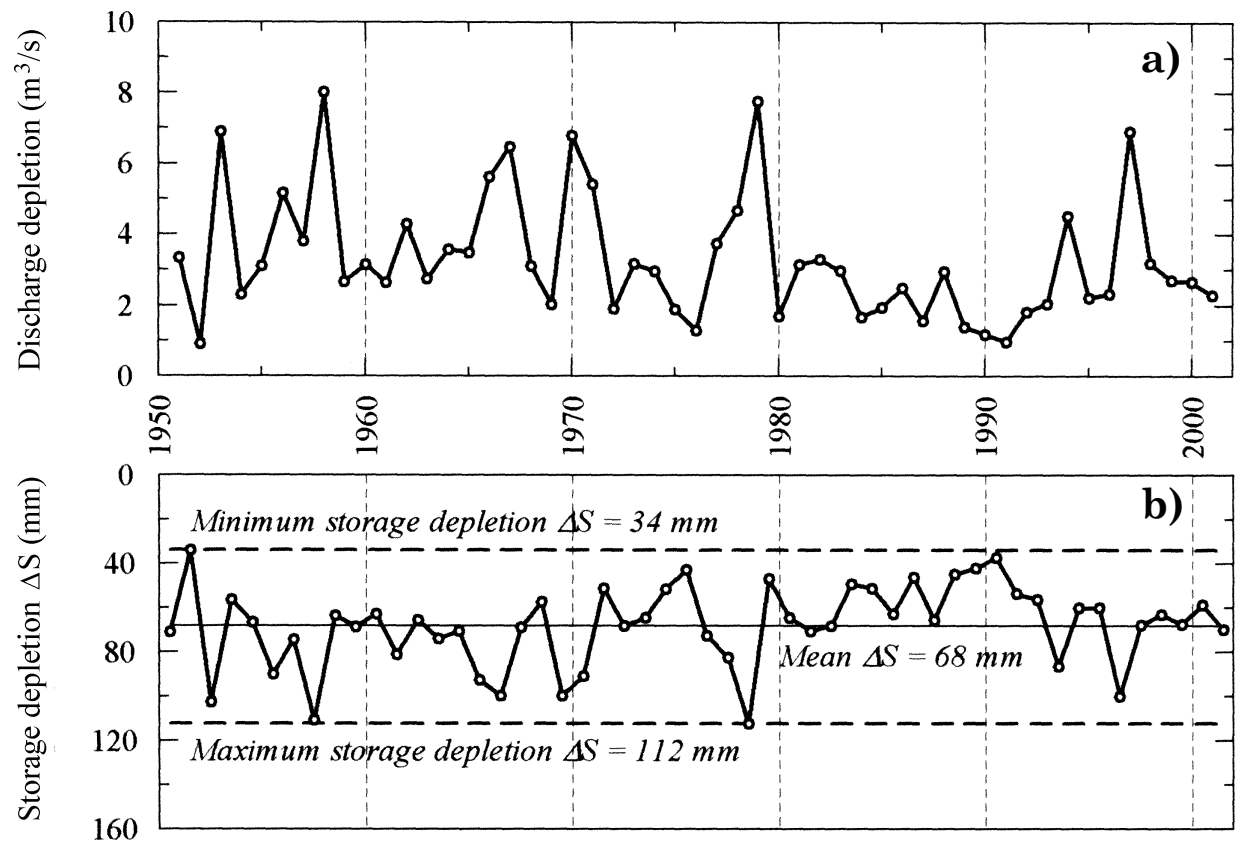

Fig. 4. Differences in the extreme discharge values in years 1951-2002 in the Easica basin at gauge Władysławów (a) and the associated depletion of the dynamic groundwater storage (b). 


\section{CONCLUSIONS}

It has been shown that using the MRC tool developed by Lamb \& Beven (1997), large number of discharge data in long-term period can be analyzed, to derive an arbitrary form of the master recession curve. The chosen form of the analytical equation can be then fitted to such derived arbitrary form of the master recession curve. In this study the equation proposed by Wittenberg (1999) was applied and parameters of the recession curves have been successfully fitted. The discharge - storage relationship was then applied to derive the depletion of dynamic groundwater storage based on extreme values of discharge data, on a yearly time step. The approach was presented on the example of lowland basin situated in central Poland, on the Mazovian Lowland.

The changes of the dynamic groundwater storage inferred by the recession curve analysis reveal the high variability in analyzed period in years 19512002. The obtained range of groundwater storage depletion characterizes the substantial dynamics of the surface-subsurface system interaction.

\section{ACKNOWLEDGEMENT}

The author would like to thank to Dr Robert Lamb from UK for making MRC tool available for the research purposes. Many thanks for revision of the program and helpful advices.

The discharge data used in the analysis were supplied by the Institute of Meteorology and Water Management in Warsaw, Poland.

\section{REFERENCES}

Jokiel P., 1987, Proces wysychania zlewni i jego fizjograficzne uwarunkowania [The recession process in the drainage area and its physiographic controls], Acta Geographica Lodziensia, Nr 56. Łódzkie Towarzystwo Naukowe, Łódź, Ossolineum.

J okiel P., 1994, Zastosowanie wzorcowej krzywej wysychania do oceny zasobów wód podziemnych i ich odnawialności [Application of standard groundwater recession curve for appraisal of underground water resources and their renewal], Wiadomości IMGW, T. XVII, $1,31-54$.

Lamb R., Beven K., 1997, Using interactive recession curve analysis to specify a general catchment storage model, Hydrology and Earth System Sciences, 1, 101-113.

Tallaksen L., 1999, A review of baseflow recession analysis, J. of Hydrology, 165, 349-370.

Tomaszewski E., 2001, Sezonowe zmiany odpływu podziemnego w Polsce w latach 19711990 [Seasonal changes of groundwater flow in Poland in the period 1971-1990], Acta Geographica Lodziensia, No 78. Łódzkie Towarzystwo Naukowe, Łódź.

Wit te n berg H., 1999, Baseflow recession and recharge as nonlinear storage process, Hydrological Processes, 13, $715-726$.

Wittenberg H., Sivapalan M., 1999, Watershed groundwater balance estimation using streamflow recession analysis and baseflow separation, J. of Hydrology, 219, 20-33.

Translated by the author 